\title{
Role of connexins and pannexins during ontogeny, regeneration, and pathologies of bone
}

\author{
Lilian I. Plotkin ${ }^{1,2^{*}}$, Dale W. Laird ${ }^{3}$ and Joelle Amedee ${ }^{4}$
}

From International Gap Junction Conference 2015

Valparaiso, Chile. 28 March - 2 April 2015

\begin{abstract}
Electron micrographs revealed the presence of gap junctions in osteoblastic cells over 40 years ago. These intercellular channels formed from connexins are present in bone forming osteoblasts, bone resorbing osteoclasts, and osteocytes (mature osteoblasts embedded in the mineralized bone matrix). More recently, genetic and pharmacologic studies revealed the role of connexins, and in particular $\mathrm{C} \times 43$, in the differentiation and function of all bone types.

Furthermore, mutations in the gene encoding Cx43 were found to be causally linked to oculodentodigital dysplasia, a condition that results in an abnormal skeleton. Pannexins, molecules with similar structure and single-membrane channel forming potential as connexins when organized as hemichannels, are also expressed in osteoblastic cells. The function of pannexins in bone and cartilage is beginning to be uncovered, but more research is needed to determine the role of pannexins in bone development, adult bone mass and skeletal homeostasis. We describe here the current knowledge on the role of connexins and pannexins on skeletal health and disease.
\end{abstract}

\section{Backgound}

Connexin (Cx) complexity: Cxs oligomerize to form hemichannels (connexons) that are transported to the cell surface where they dock with hemichannels from a contacting cell to form intercellular gap junction channels [1]. Channels typically cluster into crystalline structures known as gap junction plaques where they act to exchange numerous small molecules important in cell signalling [1]. To add to the complexity of connexin channels, undocked connexin hemichannels at the cell surface function to release small signaling molecules to the extracellular environment $[2,3]$. Gap junction channels are even more complex as connexin subunits can form homomeric or heteromeric arrangements that dock across the extracellular space to form homo- or

\footnotetext{
* Correspondence: Iplotkin@iupui.edu

'Department of Anatomy and Cell Biology, Indiana University School of Medicine, Indianapolis, IN 46202, USA

${ }^{2}$ Roudebush Veterans Administration Medical Center Indiana, Indianapolis, IN 46202, USA

Full list of author information is available at the end of the article
}

heterotypic channels. As an example, $\mathrm{Cx} 43$ has also been reported to form heterotypic channels with Cx40 [4, 5], Cx45 [6] and Cx46 [7]. Interestingly, these same connexins (Cx46, Cx45 and Cx43) are all found in the bone where they have the potential to create different types of channels with unique abilities to pass ions and small molecules as well as be regulated by $\mathrm{pH}$, voltage, and posttranslational modifications [8].

In addition to their role as membrane channels, connexins have been shown to interact with intracellular structural and signalling molecules [9], adding yet another layer of complexity to their function. In particular for bone, it has been shown that Cx43 Cterminus domain interacts with $\beta$-arrestin [10], PKC $\delta$ [11], and $\alpha 5 \beta 1$ integrins $[12,13]$ in osteoblasts and osteocytes. Further, the Cx43 C-terminus domain is required for the survival effect of bisphosphonates and parathyroid hormone, and to enhance osteoblast signaling and gene expression following FGF2 administration $[10,14,15]$. 


\section{Role of connexins on skeletal ontogeny}

Global deletion of $\mathrm{Cx} 43$ results in perinatal death due to impaired cardiac function [16], precluding the possibility to investigate the role of $\mathrm{Cx} 43$ in the mature skeleton. However, early studies performed in embryos showed delayed ossification both in intramembranous and endochondrial bone [17]. Similar results were observed in a later study [18]. This phenotype was observed in cranial bones, as well as clavicles, ribs, vertebrae and limbs. Interestingly, at the time of birth both axial and appendicular skeleton are normal, and only the cranial bones retain abnormal mineralization [17]. The expression of the osteoblastic gene osteocalcin is reduced during embryonic life (days 18.5 and 19.5 post-coitum), whereas alkaline phosphatase and osteopontin levels are reduced early on but normalized or even increased by day 19.5 [18]. In addition, osteoblasts lacking Cx43, or expressing only one copy of the gene $\left(\mathrm{Cx} 43^{+/-}\right)$isolated from newborn mice exhibit reduced expression of bone matrix proteins and reduced mineralization potential ex vivo [17]. However, bone length during development [18] as well as size and morphology of the growth plate at birth are not affected by Cx43 deletion [17].

Less is known about the role of $\mathrm{Cx} 43$ in other cell types during bone development. A study showed delayed mineralization of cranial bones at birth in mice lacking Cx43 in osteochondro progenitors, as well as in mice expressing the oculodentodigital dysplasia (ODDD) mutant $\mathrm{Cx} 43^{\mathrm{G} 138 \mathrm{R}}$ [19]. On the other hand, mice with the deletion of Cx43 in osteoblast precursors do not exhibit mineralization abnormalities, as evidence by whole mount alizarin red and alcian blue staining of newborn mice [20], suggesting that Cx43 expression in earlier precursors is needed for proper bone mineralization. In the case of other connexins that have been investigated, global deletion of Cx37 does not lead to changes in skeletal mineralization at birth [21]. Moreover, even though Cx45 and Cx46 expression has been demonstrated in bone cells, their role on skeletal development has not been studied.

\section{Mouse models of connexin deficiency and the skeleton}

As indicated above, mice with global Cx43 deletion die soon after birth, precluding the study of the adult skeleton. Absence of one $\mathrm{Cx} 43$ allele in mice expressing a floxed $\mathrm{Cx} 43$ allele $\mathrm{Cx} 43^{\mathrm{fl} /-}$ mice does not alter bone mineral density accrual or bone mass in adult mice, compared to $\mathrm{Cx} 43^{\mathrm{fl} / \mathrm{fl}}$ mice [20]. To overcome the lethality of the Cx43 full knockout, and to study the adult skeleton, several models of tissue specific deletion of $\mathrm{Cx} 43$ have been generated [22]. These mice lacking Cx43 in cells of the osteoblastic lineage have helped to understand the role of connexins in the skeleton. The bone phenotype of mice lacking Cx43 in osteoblastic cells is more striking when the gene is deleted in early progenitors, and becomes less profound when it is deleted in more mature cells. Mice lacking $\mathrm{Cx} 43$ in osteochondro progenitors (using Dermo1-Cre) exhibit decrease bone mass and reduced bone length [19]; whereas mice in which the gene is deleted in committed osteoblastic cells (Col2.3 kb-Cre) also exhibit low bone mass and decreased cancellous bone volume, but not changes in bone length $[20,23]$. Mice lacking Cx43 in mature osteoblasts (OCNCre) do not exhibit low bone mineral density or cancellous bone volume $[24,25]$, neither do mice lacking $\mathrm{Cx} 43$ in osteocytes (DMP1-8 kb-Cre) [26]. In spite of the difference in bone mineral density and the cancellous bone phenotype of these mice, they all share a cortical bone phenotype, with increased periosteal bone apposition and bone perimeter, enlarged marrow cavity and accumulation of osteoclasts on the endocortical surface of the femoral mid-diaphysis $[19,25,26]$. Further, a recent study has proposed a new role for Cx43 in osteocytes [27] mediating intracortical bone remodeling and osteocytic osteolysis, a process by which osteocytes remove the surrounding bone matrix [28].

A recent report using genetically-modified mice revealed the role of $\mathrm{Cx} 43$ channel function in osteocytes [29]. In this study, 2 transgenic mice were generated, one expressing a mutated $\mathrm{Cx} 43$ with impaired channel permeability and the other expressing a Cx43 mutant able to form functional hemichannels but unable to form gap junction channels. Mice without functional channels or hemichannels exhibit increased bone mass, whereas mice expressing a Cx43 able to form hemichannels were not different from wild type littermate controls. Further differences were found between these 2 transgenic animal models, recently reviewed [22].

Unlike Cx43 full knockout mice, Cx37 deficient mice survive until adulthood and exhibit increased bone mass due to defective osteoclast function [21]. As for bone development, the role of $\mathrm{Cx} 45$ and $\mathrm{Cx} 46$ in the adult skeleton has not been explored.

\section{Connexins and bone regeneration}

Only a few studies reported the role of $\mathrm{Cx} 43$ in bone repair and tissue regeneration in fracture healing models. Using a close femur fracture model, a recent study, revealed that $\mathrm{Cx} 43$ is widely expressed in the callus one month post-fracture [30]. Further, bone and total volume of the callus, as well as the number of TRAP+ osteoclasts are decreased in mice lacking $\mathrm{Cx} 43$ in osteoblasts and osteocytes $\left(\mathrm{Cx} 43^{\mathrm{fl} / \mathrm{fl}} ; \mathrm{OCN}-\mathrm{Cre}\right.$ mice $)$ after fracture, compared to littermate controls. $\mathrm{Cx} 43^{\mathrm{f} / \mathrm{fl}} ; \mathrm{OCN}$-Cre mice also exhibit decreased mineralization during healing, compared to control mice expressing $\mathrm{Cx} 43$ in osteoblastic 
cells. In addition, the mechanical properties of the newly formed tissue are altered in $\mathrm{Cx} 43^{\mathrm{fl} / \mathrm{fl}} ; \mathrm{OCN}$-Cre mice.

The effect of age on bone repair after damage and mechanical stimulation also involves gap junctional intercellular communication (GJIC) and Cx43 activity. For example, reduced osteocyte density and $\mathrm{Cx} 43$ levels were observed in regenerated bone in aged animals, limiting the establishment of GJIC, altering bone formation and bone resorption, as well $\mathrm{NO}$ and $\mathrm{PGE}_{2}$ secretion [31].

In contrast, in vivo transplantation of $\mathrm{Cx} 43$-transduced bone marrow stromal cells (BMSC) within gelatin scaffolds resulted in a larger quantity of bone relative to control cells. Bone regenerated from BMSC exhibiting enhanced GIC also showed a thicker cortex and a large amount of trabecular-like bone [32]. These data suggest that $\mathrm{Cx} 43$ establishes a signalling platform to improve cell to cell communication in 3-dimensional (3D) structures and may have a major impact in the design of cellbased tissue engineering strategies for enhancing bone tissue regeneration [33, 34]. Further, modulation of connexin channels might also improve cellular interactions in cell-free scaffolds, by improving the communication among host cells recruited to the 3D structures.

These data also provide new insights into the 3D approach for the establishment stimulation of cell to cell communication. Mesenchymal stem cells cultured in 3D matrices for bone tissue engineering express higher levels of $\mathrm{Cx} 43$ compared to 2D cultures in plastic culture dishes [35]. The 3D microenvironment modifies the distribution of cells cultured within the matrices and enhances the cellular contacts. Further, the spheroid organization of cells within scaffolds contributes to the increase in $\mathrm{Cx} 43$ expression and new bone formation in experimental models [35].

Osteoinductivity of calcium phosphate-based scaffolds is also likely mediated by $\mathrm{Cx} 43$ expressed by dental pulp cells [36]. These findings are expected to advance the design of future tissue engineering materials in which $\mathrm{Cx} 43$ could be used to activate bone cell differentiation and bone formation. In this context, a cell-permeant mimetic peptide, alpha connexin carboxyl-terminal peptide $(\alpha \mathrm{CT} 1)$, based on the carboxyl-terminus of $\mathrm{Cx} 43$, has been shown to elicit changes in gap junction organization and GJIC associated with upregulation of protein kinase $\mathrm{C}$-mediated phosphorylation of $\mathrm{Cx} 43$ in cell systems other than bone. It has been demonstrated that this mimetic peptide reduces scar progenitor and promotes regenerative healing following skin wounding [37] and also augments corneal wound healing [38], suggesting that it could be used to enhance bone ormation in bone scaffolds.

\section{Connexin gene mutations and human disease}

Early in the new millennium, germline mutations in the GJA1 gene encoding Cx43 were found to be causal of oculodentodigital dysplasia (ODDD) [39]. Nearly all ODDD mutations are inherited in an autosomal dominant manner and cause syndactyly, camptodactyly, craniofacial abnormalities, enamel hypoplasia, cartilage anomalies that result in a thin nose and ophthalmic defects [39-45]. There are now at least $76 \mathrm{Cx} 43$ (GJA1) mutations linked to ODDD [39-42, 45-67]. So far, $100 \%$ of the ODDD patients harbor mutations in one of the GJA1 gene alleles that encode Cx43 [61] but there are now autosomal mutations linked to $\mathrm{Cx} 43$ that do not cause ODDD but rather cranio-metaphyseal dysplasia (R239Q) [68] and sudden infant death (SID) (E42K, S272P) [69]. In addition, two recessive GJA1 mutations (encoding R33X and R76H) have been reported [41, 42, 70]. Patients homozygous for the R76 H mutant not only exhibit symptoms of ODDD but also Hallermann-Streiff syndrome denoted by a small stature, congenital cataracts, hypotrichosis, beaked nose, skeletal anomalies and teeth defects [42]. It is intriguing that specific Cx43 mutants cause different disease symptoms with variations in autosomal dominant or recessive inheritance and it is intriguing that nearly all mutants cause bone abnormalities.

\section{Cx43 gene mutations cause disease by different mechanisms}

Many categories of disease-linked Cx43 mutants have been identified which include changes in connexin halflife, dysregulated $\mathrm{pH}$ and/or voltage gating and assembly defects that lead to loss- or gain- of channel or hemichannel function [60]. Of the documented mechanisms, one group includes mutants that assemble into gap junction channels (I130T [71-74]) but have known reductions in channel function. Another class of mutants includes those with altered intracellular trafficking, typically resulting in mutants being retained in the endoplasmic reticulum and/ or Golgi apparatus (fs230, fs260 [75, 76]). Still other mutants fall into a class that have a gain-of-function where hemichannel (G138R [77]), or channel function is enhanced beyond what is observed for wild-type Cx43 (G143S). Finally, Cx43 mutants may be efficiently transported to the cell surface and assemble into gap junction plaques, but remain functionally dead (G21R [78]). Collectively, these findings suggest that specific mutations may exhibit distinct mechanisms of action that have direct bearing on the clinical presentation of ODDD.

Disease-linked mutants are co-expressed with wildtype $\mathrm{Cx} 43$ and may contribute to the overall level of Cx43-based GJIC if functionally active, or alternatively, inhibited wild type $\mathrm{Cx} 43$ function if functionally dead. For example, the I130T mutant exhibits 20\% normal channel function when expressed alone [73] and, together with co-expressed wild-type Cx43, maintains Cx43-based GJIC at $>50 \%[72,73,79]$. In other cases, the mutant may be dominant-negative to co-expressed 
wild-type Cx43 (G21R, fs260 [76, 78, 80, 81]) resulting in total Cx43-based GJIC to be $<50 \%$. Since nearly all human cells co-express Cx43 along with other connexin family members, the mutants have the theoretical potential to exhibit transdominant negative properties on other connexins. This condition seems to be rare as the hearts of ODDD patients, for example, are rarely diseased. However, bone anomalies are common in ODDD patients where osteoblasts and osteocytes express Cx37, Cx45 and Cx46 [82-88] all of which can potentially interact with co-expressed $\mathrm{Cx} 43$.

\section{Cx43 in bone and cartilage}

Bone development, remodeling and repair require the exquisite and coordinated activity of osteoprogenitor cells, osteoblasts, osteocytes and osteoclasts all of which express $\mathrm{Cx} 43$ that mediates both hemichannel function and GJIC [86, 87, 89, 90]. While Cx43 is by far the predominant connexin in cells of osteogenic lineage, Cx37, Cx45 and Cx46 have also been found [89]. Several reports using $\mathrm{Cx} 43$ knockout mice and conditional ablation of Cx43 from osteoblasts and osteocytes during early development have demonstrated excessive endocortical bone resorption together with periosteal enlarging resulting in reduced whole body bone mass together with cortical widening and thinning [20, 26, 91-93]. Connexins in cartilage are less well understood but $\mathrm{Cx} 43$ is again the predominant connexins in mesenchymal cells and chondrocytes [94-98] while Cx45, Cx32, and Cx46 expression have also been reported [99]. Collectively, these studies suggest that Cx43 plays an essential role in skeletal development. In addition, increasing evidence supports the notion that $\mathrm{Cx} 43$ also plays a key role during bone remodeling in aging, as its ablation has been reported to desensitize osteoclasts that typically become activated after the removal of mechanical load [100]. Further, the increase in GJIC in response to PTH and cholera toxin is diminished in cells from old (12-month-old) compared to young (4-month-old) rats [101]. We know that ODDD patients consistently exhibit craniofacial anomalies yet little information exists as to whether there are changes in long bones. Phenotypic evaluation of $\mathrm{Cx} 43^{\mathrm{G} 60 \mathrm{~S} /+}$ mice revealed thinner cortical bones, enlarged marrow cavity, decreased mineral density, a decline in trabecular bone volume and reduced overall mechanical strength [102]. Most recently, these mice were found to have higher levels of osteoprogenitor cells and greater osteoblast function leading to the up-regulation of bone sialoprotein and the receptor activator of $\mathrm{NF}_{\kappa} \mathrm{B}$ ligand [103]. While young mutant mice had greater osteoclast number leading to osteopenia, this condition was self-corrected during aging [103]. In a second conditional mouse model of ODDD where the G138R mutant was introduced into cells of osteochondro lineage, skulls were found to be smaller and whole body bone mineral density was less as the mice suffered from cortical thinning [19]. Thus, while it is clear that Cx43 plays a key role in bone development and remodeling the mechanisms involved remain largely unknown and it has yet to be determined how these skeletal changes manifest during bone fracture and healing. In addition, we have little knowledge of how ODDD mutants affect hemichannel and gap junction channel status in cells of osteogenic lineage. Hemichannel function, in particular, is of considerable interest as several studies have shown that shear stressinduced opening of hemichannels allows the release of prostaglandins and ATP resulting in the activation of paracrine signaling pathways $[89,104]$. The importance of these findings is enhanced by the fact that at least a few ODDD mutations (e.g., G138R) result in gain-of-hemichannel function [77].

Cx43 has been shown to be involved in the response of the skeleton to different insults. For example, mice lacking Cx43 in osteoblastic cells and subjected to ovariectomy, a well-known maneuver to mimic post-menopausal bone loss, does not lose bone mass 3 weeks after surgery, unlike littermate wild type controls [105]. However, bone mineral density in Cx43-deficient mice reaches similar values to those of wild type mice 4 weeks post-ovariectomy, suggesting that bone loss induced by lack of sex steroids is delayed, but not abolished, in the absence of osteoblastic Cx43.

In addition to its role in skeletal development and bone cell function, in vitro and in vivo evidence supports a role of $\mathrm{Cx} 43$ on bone acting stimuli. In particular, the survival effect of bisphosphonates and parathyroid hormone (agents used to treat osteoporosis and other bone diseases) on osteoblastic cells required $\mathrm{Cx} 43$ expression in vitro $[10,14]$. The requirement of $\mathrm{Cx} 43$ for bisphosphonate survival effect has been confirmed in vivo, in mice lacking Cx43 in osteoblasts and osteocytes [24]. Further, the bone anabolic effect of intermittent parathyroid hormone administration is diminished in mice lacking Cx43 in osteoblastic cells [20].

Cx43 has also been involved in the effect of mechanical stimulation on the skeleton. In particular, mice lacking Cx43 in osteochondro progenitors, in osteoblastic cells, or in osteocytes exhibit an increased response to mechanical stimulation in bone $[25,26,106]$. Further, $C x 43$ deletion from osteoblastic cells attenuates bone loss induced by reduced mechanical forces $[93,107]$.

\section{Pannexins}

Upon their discovery in the new millennium, pannexins (Panxs) gained instant attention as a possible new family of gap junction proteins due to their limited homology to invertebrate gap junction proteins [108]. The pannexin 
family of channel proteins consists of Panx1, Panx2 and Panx3. Through the use of a molecular toolkit it was discovered that members of the pannexin family are long-lived, channel-forming glycoproteins that function in ATP release [109-111]. While the proposed role of pannexins as molecular constituents of intercellular channels remains unlikely, there is general agreement that Panx1 forms large single membrane channels at the cell surface that serve a role in paracrine signaling [112]. For example, Panx1- [113] and Panx3-mediated [114] ATP release plays a role in calcium wave propagation which may involve their interplay with purinergic receptors [115-118]. ATP and UTP released via Panx1 channels also serves as "find-me" signals for clear apoptotic cells [110]. Signaling through Panx1 channels may also contribute to cell death and seizures under ischemic or epileptic conditions [119-121], lead to inflammatory bowel disease [116], promote melanoma disease progression [122] and even facilitate HIV-1 viral infection [123]. Panx3 has been linked to the proliferation/differentiation of keratinocytes [124], chondrocytes $[125,126]$ and osteoblasts $[114,125,127]$. Other studies highlighted the regulatory role of Panx1 and Panx3 in keratinocyte differentiation while Panx3 was found to be important in osteoprogenitor cells, chondrocytes and osteoblasts [124, 125, 127]. Amongst a variety of tissues, Panx 1 mRNA and protein has been detected in the developing and mature cartilage and bone [109, 112, 128]. Panx3 has a more restricted distribution pattern in the body but widely found in skeletal tissue, including prehypertrophic chondrocytes and perichondrium osteoblasts [112]. In addition, a recent study showed that Panx2 is present in extracellular matrix vesicles obtained from mineralizing osteoblastic cells [129].

\section{Role of pannexins in skeletal tissues}

It is now well established that Panx3 is expressed in cartilage where it may regulate chondrocyte proliferation and differentiation $[125,126]$. This notion is supported by the up-regulation of Panx3 during terminal differentiation of chondrocytes [130, 131]. Panx 3 was also found to be of critical importance in the maturation of growth plates in the chicken embryo. Interestingly the expression of Panx3 in N1511 and ATDC5 cells promoted differentiation of chondrocytes which was inhibited in Panx3 knockdown studies [126]. Chondrocyte differentiation was further linked to the reduction and in cAMP and ATP release [126]. Through what might be attributed to calcium waves and ATP release, Panx3 appears to govern osteoblast differentiation [114]. Consistent with our studies showing Panx3 expression in skeletal tissues and its regulation by the skeletal master transcription factor Runx2 [125], it is highly likely that Panx3 plays a key role in cartilage and bone development. The involvement of pannexin channels in acquired pathological conditions has only been reported in skeletal muscle atrophy [132].

Mice with global deletion of Panx1, 2 and 3 have been generated, as well as double Panx1/2 knock outs [133, 134]. All these mice are viable; however, the consequences of pannexin deletion on bone/cartilage phenotypes (or lack thereof) have not been reported, except in the case of Panx3 where it appears to play a role in osteoarthritis (see below).

\section{Connexins and pannexins in osteoarthritis}

Osteoarthritis is a progressive disease of the joint affecting over $15 \%$ of the world population [135]. This untreatable disease tends to affect the aging population as multiple joints experience articular cartilage degeneration which includes deterioration of the synovium, bone and ligaments localized to joints [136, 137]. Molecular mechanisms that govern this process are ill-defined but appear to include changes that result in aberrant hypertrophic differentiation of articular chondrocytes $[138,139]$.

\section{Role of connexins}

Several studies over the last few years show a correlation between aberrant $\mathrm{Cx} 43$ expression and OA. In particular, $\mathrm{Cx} 43$ expression and the presence of gap junction plaques is increased in synovial lining cells isolated from the knees of patients with OA [140]; and Cx43 levels are elevated in the cartilage of the knees and femoral heads [99] and in the shoulders [141] of patients with osteoarthritis. In addition, $\mathrm{Cx} 43$ levels in osteoarthritic cartilage correlate with the expression of several pro-inflammatory and catabolic factors [141]. Further support for a role of $\mathrm{Cx} 43$ in cartilage is provided by the protection of inflammation and joint destruction by silencing Cx43 in a model of rheumatoid arthritis in rats [142]. In addition, a recent proteomic study showed that the profile of $\mathrm{Cx} 43$-interacting proteins changes in primary chondrocytes isolated from patients with OA, compared to normal donors [143].

\section{Role of pannexins}

Panx3 has been shown to have a potentially important role in $\mathrm{OA}$ as it was found to be upregulated in the reticular cartilage of rats surgically treated to accelerate the onset of OA [144]. A few years later this notion was further supported by Iwamoto and colleagues [126] as they found that knockdown of Panx3 blocked hypertrophic chondrocyte differentiation. As an extension to these studies the first global and cartilage-specific Panx3 null mice were generated and subjected to OA onset by destabilization of the medial meniscus surgery [134]. In both cases, mice lacking Panx3 developed less severe OA. Not surprisingly when human biopsies from OA 


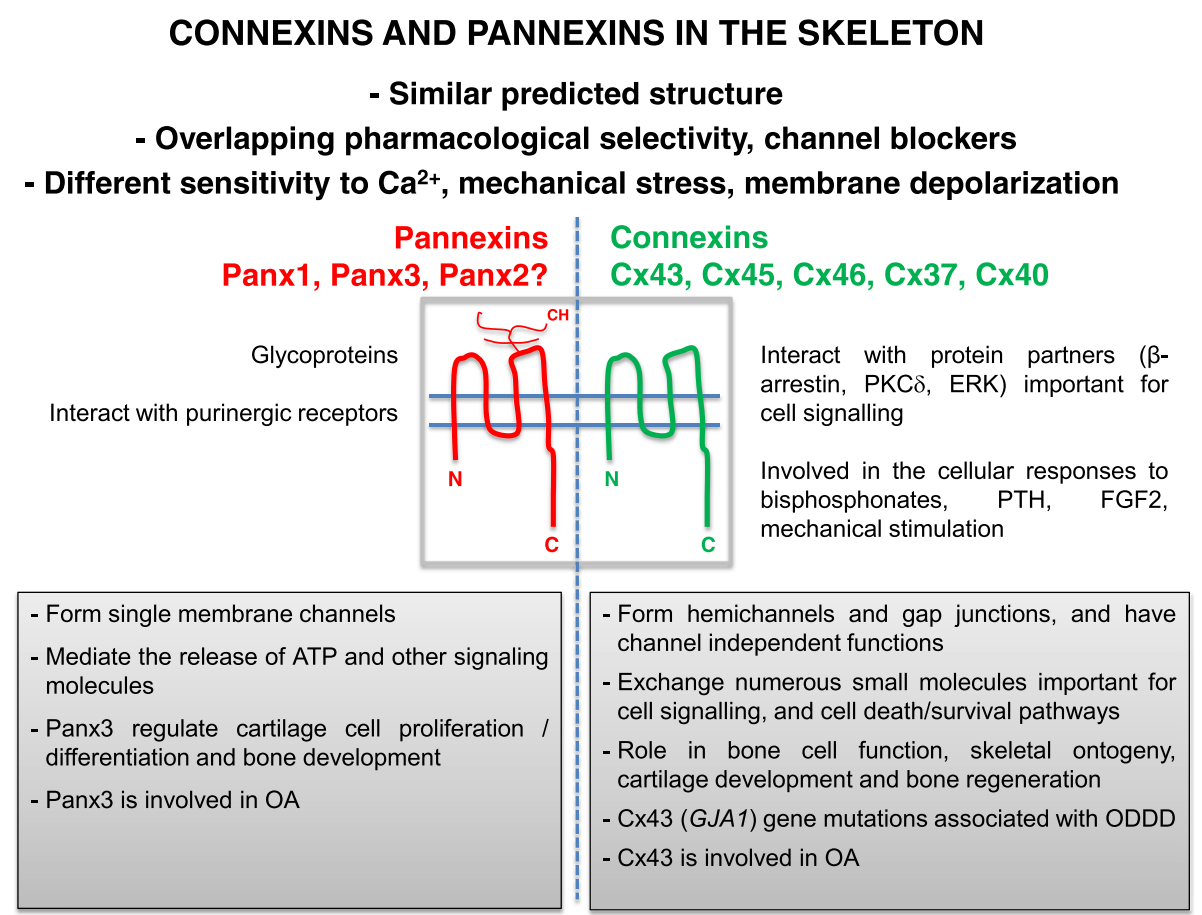

Fig. 1 Figure summarizes the current understanding on the role of connexins and pannexins in the skeleton. OA, osteoarthritis; ODDD, oculodentodigito dysplasia; $\mathrm{CH}$, carbohydrate chain

patients were assessed and compared to OA in mice, both exhibited high levels of Panx3 suggesting that Panx3 was instrumental in the development of $\mathrm{OA}$ [134]. Current studies are underway by this same team to determine if Panx1 serves any role in OA onset and progression. Nevertheless, these studies suggest that Panx3 may be a potential target in the treatment of OA.

\section{Conclusion}

Mounting evidence supports a central role of $\mathrm{Cx} 43$ for skeletal development, maintenance, and response to bone acting stimuli (Fig. 1). Further, mutations of the Cx43 gene in humans are linked to ODDD, a disease with skeletal manifestations. On the other hand, the role of pannexins in the skeleton is beginning to be uncovered, and pannexins seem to have a more relevant function in cartilage than in bone.

Genetically-modified animal models have provided fundamental information on the role of connexins and pannexins in skeletal tissue. However, similarities and differences between connexins and pannexins still remained enigmatic. Basically, ascribing a particular function to connexins vs. pannexins on the effects of bone acting stimuli and for skeletal disease remains a difficult problem plagued by the overlapping pharmacological selectivity between channels, compensation by the others isoforms, methodological differences in assessing channel function, and genetic alterations associated with transgenic mouse models [145]. Therefore, better tools are needed to understand the role of these channels in bone and cartilage. Furthermore, a fundamental task for future research is to find compounds that specifically modulate the actions of connexins or pannexins, allowing their use as pharmacological agents to treat diseases of the skeleton.

Competing interests

The authors declare that no conflict of interest exists.

Authors' contributions

LIP, DWL and JA wrote the manuscript and read and approved the final version.

Acknowledgements

The authors thank Hannah M. Davis and Emily G. Atkinson for their help in preparing the manuscript.

\section{Declarations}

The publication charges for this article were funded by the National Institutes of Health (R01-AR053643 and R01-AR067210) to LIP, Canadian Institutes of Health

Research (130530) to DWL, and INSERM (National Institute for Health and Medical Research), University of Bordeaux and National Research Agency to JA.

This article has been published as part of BMC Cell Biology Volume 17 Supplement 1, 2016: Proceedings of the International Gap Junction Conference 2015. The full contents of the supplement are available online at http:// bmccellbiol.biomedcentral.com/articles/supplements/volume-17-supplement-1.

\section{Author details}

${ }^{1}$ Department of Anatomy and Cell Biology, Indiana University School of Medicine, Indianapolis, IN 46202, USA. ${ }^{2}$ Roudebush Veterans Administration Medical Center Indiana, Indianapolis, IN 46202, USA. ${ }^{3}$ Department of Anatomy and Cell Biology, University of Western Ontario, London, Ontario N6A-5C1, Canada. ${ }^{4}$ INSERM U1026, Tissue Bioengineering, Université Bordeaux, Bordeaux F-33076, France. 
Published: 24 May 2016

\section{References}

1. Goodenough DA, Goliger JA, Paul DL. Connexins, connexons, and intercellular communication. Annu Rev Biochem. 1996;65:475-502.

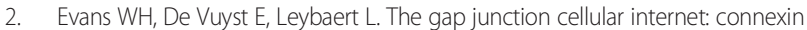
hemichannels enter the signalling limelight. Biochem J. 2006;397:1-14.

3. Goodenough DA, Paul DL. Beyond the gap: functions of unpaired connexon channels. Nat Rev Mol Cell Biol. 2003;4:285-94.

4. Cottrell GT, Burt JM. Heterotypic gap junction channel formation between heteromeric and homomeric Cx40 and Cx43 connexons. Am J Physiol Cell Physiol. 2001;281:C1559-67.

5. Valiunas $V$, Weingart R, Brink PR. Formation of heterotypic gap junction channels by connexins 40 and 43. Circ Res. 2000;86:E42-9.

6. Rackauskas M, Verselis VK, Bukauskas FF. Permeability of homotypic and heterotypic gap junction channels formed of cardiac connexins $m C \times 30.2$, Cx40, Cx43, and Cx45. Am J Physiol Heart Circ Physiol. 2007;293:H1729-36.

7. Qu Y, Dahl G. Function of the voltage gate of gap junction channels: selective exclusion of molecules. Proc Natl Acad Sci U S A. 2002;99:697-702.

8. Harris AL. Connexin channel permeability to cytoplasmic molecules. Prog Biophys Mol Biol. 2007:94:120-43.

9. Herve JC, Derangeon M, Sarrouilhe D, Giepmans BN, Bourmeyster N. Gap junctional channels are parts of multiprotein complexes. Biochim Biophys Acta. 2012;1818:1844-65.

10. Bivi N, Lezcano V, Romanello M, Bellido T, Plotkin LI. Connexin43 interacts with ßarrestin: a pre-requisite for osteoblast survival induced by parathyroid hormone. J Cell Biochem. 2011;112:2920-30.

11. Niger C, Hebert C, Stains JP. Interaction of connexin43 and protein kinase Cdelta during FGF2 signaling. BMC Biochem. 2010;11:14.

12. Batra N, Burra S, Siller-Jackson AJ, Gu S, Xia X, Weber GF, Desimone D, Bonewald LF, Lafer EM, Sprague E, Schwartz MA, Jiang JX. Mechanical stress-activated integrin alpha5beta1 induces opening of connexin 43 hemichannels. Proc Natl Acad Sci U S A. 2012;109:3359-64.

13. Batra N, Riquelme MA, Burra S, Rekha K, Gu S, Jiang JX. Direct Regulation of Osteocytic Connexin 43 Hemichannels through AKT Kinase Activated by Mechanical Stimulation. J Biol Chem. 2014;289:10582-91.

14. Plotkin LI, Manolagas SC, Bellido T. Transduction of cell survival signals by connexin-43 hemichannels. J Biol Chem. 2002;277:8648-57.

15. Hebert C, Stains JP. An intact connexin43 is required to enhance signaling and gene expression in osteoblast-like cells. J Cell Biochem. 2013;114:2542-50.

16. Reaume AG, de Sousa PA, Kulkarni S, Langille BL, Zhu D, Davies TC, Juneja SC, Kidder GM, Rossant J. Cardiac malformation in neonatal mice lacking connexin43. Science. 1995;267:1831-4.

17. Lecanda F, Warlow PM, Sheikh S, Furlan F, Steinberg TH, Civitelli R. Connexin43 deficiency causes delayed ossification, craniofacial abnormalities, and osteoblast dysfunction. J Cell Biol. 2000;151:931-44.

18. Chaible LM, Sanches DS, Cogliati B, Mennecier G, Dagli ML. Delayed Osteoblastic Differentiation and Bone Development in Cx43 Knockout Mice. Toxicol Pathol. 2011:39:1046-55.

19. Watkins M, Grimston SK, Norris JY, Guillotin B, Shaw A, Beniash E, Civitelli R. Osteoblast Connexin43 modulates skeletal architecture by regulating both arms of bone remodeling. Mol Biol Cell. 2011;22:1240-51.

20. Chung D, Castro CH, Watkins M, Stains JP, Chung MY, Szejnfeld VL, Willecke K, Theis M, Civitelli R. Low peak bone mass and attenuated anabolic response to parathyroid hormone in mice with an osteoblast-specific deletion of connexin43. J Cell Sci. 2006;119:4187-98.

21. Pacheco-Costa R, Hassan I, Reginato RD, Davis HM, Bruzzaniti A, Allen MR, Plotkin LI. High Bone Mass in Mice Lacking Cx37 Due to Defective Osteoclast Differentiation. J Biol Chem. 2014;289:8508-20.

22. Plotkin LI, Stains JP. Connexins and pannexins in the skeleton: gap junctions, hemichannels and more. Cell Mol Life Sci. 2015;72(15): 2853-67.

23. Shen H, Grimston S, Civitelli R, Thomopoulos S. Deletion of connexin43 in osteoblasts/osteocytes leads to impaired muscle formation in mice. J Bone Miner Res. 2014;30:596-605.

24. Plotkin LI, Lezcano V, Thostenson J, Weinstein RS, Manolagas SC, Bellido T. Connexin 43 is required for the anti-apoptotic effect of bisphosphonates on osteocytes and osteoblasts in vivo. J Bone Miner Res. 2008;23:1712-21.
25. Zhang Y, Paul EM, Sathyendra V, Davidson A, Bronson S, Srinivasan S, Gross TS, Donahue HJ. Enhanced osteoclastic resorption and responsiveness to mechanical load in gap junction deficient bone. PLoS One. 2011;6, e23516.

26. Bivi N, Condon KW, Allen MR, Farlow N, Passeri G, Brun L, Rhee $Y$, Bellido T, Plotkin LI. Cell autonomous requirement of connexin 43 for osteocyte survival: consequences for endocortical resorption and periosteal bone formation. J Bone Min Res. 2012;27:374-89.

27. Lloyd SA, Loiselle AE, Zhang Y, Donahue HJ. Evidence for the role of connexin 43-mediated intercellular communication in the process of intracortical bone resorption via osteocytic osteolysis. BMC Musculoskelet Disord. 2014;15:122.

28. Bonewald LF. The Amazing Osteocyte. J Bone Miner Res. 2011;26:229-38.

29. Xu H, Gu S, Riquelme MA, Burra S, Callaway D, Cheng H, Guda T, Schmitz J, Fajardo RJ, Werner SL, Zhao H, Shang P, Johnson ML, Bonewald LF, Jiang JX. Connexin 43 Channels are Essential for Normal Bone Structure and Osteocyte Viability. J Bone Miner Res. 2015;30:550-62.

30. Loiselle AE, Paul EM, Lewis GS, Donahue HJ. Osteoblast and osteocyte-specific loss of Connexin43 results in delayed bone formation and healing during murine fracture healing. J Orthop Res. 2013;31:147-54.

31. Joiner DM, Tayim RJ, McElderry JD, Morris MD, Goldstein SA. Aged male rats regenerate cortical bone with reduced osteocyte density and reduced secretion of nitric oxide after mechanical stimulation. Calcif Tissue Int. 2014:94:484-94.

32. Rossello RA, Wang Z, Kizana E, Krebsbach PH, Kohn DH. Connexin 43 as a signaling platform for increasing the volume and spatial distribution of regenerated tissue. Proc Natl Acad Sci U S A. 2009;106:13219-24.

33. Rossello RA, H D. Cell communication and tissue engineering. Commun Integr Biol. 2010;3:53-6.

34. Grellier M, Bordenave L, Amedee J. Cell-to-cell communication between osteogenic and endothelial lineages: implications for tissue engineering. Trends Biotechnol. 2009;27:562-71.

35. Guerrero J, Catros S, Derkaoui SM, Lalande C, Siadous R, Bareille R, Thebaud N, Bordenave L, Chassande O, Le VC, Letourneur D, Amedee J. Cell interactions between human progenitor-derived endothelial cells and human mesenchymal stem cells in a three-dimensional macroporous polysaccharide-based scaffold promote osteogenesis. Acta Biomater. 2013:9:8200-13.

36. Syed-Picard FN, Jayaraman T, Lam RS, Beniash E, Sfeir C. Osteoinductivity of calcium phosphate mediated by connexin 43. Biomaterials. 2013;34:3763-74.

37. Ghatnekar GS, O'Quinn MP, Jourdan $\sqcup$, Gurjarpadhye AA, Draughn RL, Gourdie RG. Connexin43 carboxyl-terminal peptides reduce scar progenitor and promote regenerative healing following skin wounding. Regen Med. 2009;4:205-23.

38. Moore K, Bryant ZJ, Ghatnekar G, Singh UP, Gourdie RG, Potts JD. A synthetic connexin 43 mimetic peptide augments corneal wound healing. Exp Eye Res. 2013;115:178-88.

39. Paznekas WA, Boyadjiev SA, Shapiro RE, Daniels O, Wollnik B, Keegan CE, Innis JW, Dinulos MB, Christian C, Hannibal MC, Jabs EW. Connexin 43 (GJA1) mutations cause the pleiotropic phenotype of oculodentodigital dysplasia. Am J Hum Genet. 2003;72:408-18.

40. de la Parra DR, Zenteno JC. A new GJA1 (connexin 43) mutation causing oculodentodigital dysplasia associated to uncommon features. Ophthalmic Genet. 2007:28:198-202.

41. Joss SK, Ghazawy S, Tomkins S, Ahmed M, Bradbury J, Sheridan E. Variable expression of neurological phenotype in autosomal recessive oculodentodigital dysplasia of two sibs and review of the literature. Eur J Pediatr. 2008;167:341-5.

42. Pizzuti A, Flex E, Mingarelli R, Salpietro C, Zelante L, Dallapiccola B. A homozygous GJA1 gene mutation causes a Hallermann-Streiff/ODDD spectrum phenotype. Hum Mutat. 2004;23:286

43. Loddenkemper T, Grote K, Evers S, Oelerich M, Stogbauer F. Neurological manifestations of the oculodentodigital dysplasia syndrome. J Neurol. 2002; 249:584-95.

44. Van Es AC, Van Der Flier WM, Dmiraal-Behloul F, Olofsen H, Bollen EL, Middelkoop HA, Weverling-Rijnsburger AW, Van Der GJ, Westendorp RG, Van Buchem MA. Lobar distribution of changes in gray matter and white matter in memory clinic patients: detected using magnetization transfer imaging. AJNR Am J Neuroradiol. 2007;28:1938-42.

45. Vreeburg M, De Zwart-Storm EA, Schouten MI, Nellen RG, Marcus-Soekarman D, Devies M, Van GM, Van Steensel MA. Skin changes in oculo-dento-digital dysplasia are correlated with C-terminal truncations of connexin 43. Am J Med Genet A. 2007;143:360-3

46. Alao MJ, Bonneau D, Holder-Espinasse M, Goizet C, Manouvrier-Hanu S, Mezel A, Petit F, Subtil D, Magdelaine C, LaCombe D. Oculo-dento-digital dysplasia: lack of genotype-phenotype correlation for GJA1 mutations and usefulness of neuro-imaging. Eur J Med Genet. 2010;53:19-22. 
47. Brice G, Ostergaard P, Jeffery S, Gordon K, Mortimer PS, Mansour S. A novel mutation in GJA1 causing oculodentodigital syndrome and primary lymphoedema in a three generation family. Clin Genet. 2013;84:378-81.

48. Himi M, Fujimaki T, Yokoyama T, Fujiki K, Takizawa T, Murakami A. A case of oculodentodigital dysplasia syndrome with novel GJA1 gene mutation. Jpn J Ophthalmol. 2009:53:541-5.

49. Gabriel LA, Sachdeva R, Marcotty A, Rockwood E, Traboulsi El. Oculodentodigital dysplasia: new ocular findings and a novel connexin 43 mutation. Arch Ophthalmol. 2011;129:781-4

50. Furuta N, Ikeda M, Hirayanagi K, Fujita Y, Amanuma M, Okamoto K. A novel GJA1 mutation in oculodentodigital dysplasia with progressive spastic paraplegia and sensory deficits. Intern Med. 2012;51:93-8.

51. Fenwick A, Richardson RJ, Butterworth J, Barron MJ, Dixon MJ. Novel mutations in GJA1 cause oculodentodigital syndrome. J Dent Res. 2008;87:1021-6.

52. Debeer P, Van EH, Huysmans C, Pijkels E, De SL, Van D, Devriendt VK, Fryns JP. Novel GJA1 mutations in patients with oculo-dento-digital dysplasia (ODDD). Eur J Med Genet. 2005;48:377-87.

53. Kjaer KW, Hansen L, Eiberg H, Leicht P, Opitz JM, Tommerup N. Novel Connexin 43 (GJA1) mutation causes oculo-dento-digital dysplasia with curly hair. Am J Med Genet. 2004;127A:152-7.

54. Itro A, Marra A, Urciuolo V, Difalco P, Amodio A. Oculodentodigital dysplasia. A case report. Minerva Stomatol. 2005;54:453-9.

55. Izumi K, Lippa AM, Wilkens A, Feret HA, Donald-McGinn DM, Zackai EH. Congenital heart defects in oculodentodigital dysplasia: Report of two cases. Am J Med Genet A. 2013;161A:3150-4.

56. Jamsheer A, Sowinska-Seidler A, Socha M, Stembalska A, Kiraly-Borri C, Latos-Bielenska A. Three novel GJA1 missense substitutions resulting in oculo-dento-digital dysplasia (ODDD) - further extension of the mutational spectrum. Gene. 2014;539:157-61.

57. Jamsheer A, Wisniewska M, Szpak A, Bugaj G, Krawczynski MR, Budny B, Wawrocka A, Latos-Bielenska A. A novel GJA1 missense mutation in a Polish child with oculodentodigital dysplasia. J Appl Genet. 2009;50:297-9.

58. Kellermayer R, Keller M, Ratajczak P, Richardson E, Harangi F, Merei E, Melegh B, Kosztolanyi G, Richard G. Bigenic connexin mutations in a patient with hidrotic ectodermal dysplasia. Eur J Dermatol. 2005;15:75-9.

59. Kelly SC, Ratajczak P, Keller M, Purcell SM, Griffin T, Richard G. A novel GJA 1 mutation in oculo-dento-digital dysplasia with curly hair and hyperkeratosis. Eur J Dermatol. 2006:16:241-5.

60. Laird DW. Syndromic and non-syndromic disease-linked Cx43 mutations. FEBS Lett. 2014:588:1339-48.

61. Paznekas WA, Karczeski B, Vermeer S, Lowry RB, Delatycki M, Laurence F, Koivisto PA, Van ML, Boyadjiev SA, Bodurtha, JN, Jabs EW, GJA1 mutations, variants, and connexin 43 dysfunction as it relates to the oculodentodigital dysplasia phenotype. Hum Mutat. 2009;30:724-33.

62. Honkaniemi J, Kalkkila JP, Koivisto P, Kahara V, Latvala T, Simola K. Letter to the editor: Novel GJA1 mutation in oculodentodigital dysplasia. Am J Med Genet A. 2005:139:48-9.

63. Richardson R, Donnai D, Meire F, Dixon MJ. Expression of Gja1 correlates with the phenotype observed in oculodentodigital syndrome/type III syndactyly. J Med Genet. 2004;41:60-7.

64. Van Steensel MA, Spruijt L, Van DB, Bladergroen IRS, Vermeer M, Steijlen PM, Van GM. A 2-bp deletion in the GJA1 gene is associated with oculo-dento-digital dysplasia with palmoplantar keratoderma. Am J Med Genet A. 2005;132A:171-4.

65. Vasconcellos JP, Melo MB, Schimiti RB, Bressanim NC, Costa FF, Costa VP. A novel mutation in the GJA1 gene in a family with oculodentodigital dysplasia. Arch Ophthalmol. 2005;123:1422-6.

66. Vitiello C, D'Adamo P, Gentile F, Vingolo EM, Gasparini P, Banfi S. A novel GJA1 mutation causes oculodentodigital dysplasia without syndactyly. Am J Med Genet A. 2005;133A:58-60.

67. Wiest T, Herrmann O, Stogbauer F, Grasshoff U, Enders H, Koch MJ, Grond-Ginsbach C, Schwaninger M. Clinical and genetic variability of oculodentodigital dysplasia. Clin Genet. 2006;70:71-2.

68. Hu Y, Chen IP, De AS, Tiziani V, Do Amaral CM, Gowrishankar K, Passos-Bueno MR, Reichenberger EJ. A novel autosomal recessive GJA1 missense mutation linked to Craniometaphyseal dysplasia. PLoS One. 2013;8:e73576.

69. Van Norstrand DW, Asimaki A, Rubinos C, Dolmatova E, Srinivas M, Tester DJ, Saffitz JE, Duffy HS, Ackerman MJ. Connexin43 mutation causes heterogeneous gap junction loss and sudden infant death. Circulation. 2012;125:474-81.

70. Richardson R, Joss S, Tomkin S, Ahmed M, Sheridan E, Dixon MJ. A nonsense mutation in the first transmembrane domain of connexin 43 underlies autosomal recessive oculodentodigital syndrome. J Med Genet. 2006;43:e37.
71. Huang T, Shao Q, Barr K, Simek J, Fishman Gl, Laird DW. Myogenic bladder defects in mouse models of human oculodentodigital dysplasia. Biochem J. 2014:457:441-9.

72. Kalcheva N, Qu J, Sandeep N, Garcia L, Zhang J, Wang Z, Lampe PD, Suadicani SO, Spray DC, Fishman Gl. Gap junction remodeling and cardiac arrhythmogenesis in a murine model of oculodentodigital dysplasia. Proc Natl Acad Sci U S A. 2007;104:20512-6.

73. Stewart MK, Gong XQ, Barr KJ, Bai D, Fishman Gl, Laird DW. The severity of mammary gland developmental defects is linked to the overall functional status of Cx43 as revealed by genetically modified mice. Biochem J. 2013;449:401-13.

74. Shibayama J, Paznekas W, Seki A, Taffet S, Jabs EW, Delmar M, Musa H. Functional characterization of connexin43 mutations found in patients with oculodentodigital dysplasia. Circ Res. 2005:96:e83-91.

75. Churko JM, Langlois S, Pan X, Shao Q, Laird DW. The potency of the fs 260 connexin43 mutant to impair keratinocyte differentiation is distinct from other disease-linked connexin43 mutants. Biochem J. 2010;429:473-83.

76. Gong XQ, Shao Q, Lounsbury CS, Bai D, Laird DW. Functional characterization of a GJA1 frameshift mutation causing oculodentodigital dysplasia and palmoplantar keratoderma. J Biol Chem. 2006;281:31801-11.

77. Dobrowolski R, Sommershof A, Willecke K. Some oculodentodigital dysplasiaassociated cx43 mutations cause increased hemichannel activity in addition to deficient gap junction channels. J Membr Biol. 2007;219:9-17.

78. Gong XQ, Shao Q, Langlois S, Bai D, Laird DW. Differential potency of dominant negative connexin43 mutants in oculodentodigital dysplasia. J Biol Chem. 2007;282:19190-202

79. Huang T, Shao Q, MacDonald A, Xin L, Lorentz R, Bai D, Laird DW. Autosomal recessive GJA1 (Cx43) gene mutations cause oculodentodigital dysplasia by distinct mechanisms. J Cell Sci. 2013;126:2857-66.

80. McLachlan E, Manias JL, Gong XQ, Lounsbury CS, Shao Q, Bernier SM, Bai D, Laird DW. Functional characterization of oculodentodigital dysplasiaassociated Cx43 mutants. Cell Commun Adhes. 2005;12:279-92.

81. Roscoe W, Veitch Gl, Gong XQ, Pellegrino E, Bai D, McLachlan E, Shao Q, Kidder GM, Laird DW. Oculodentodigital dysplasia-causing connexin43 mutants are non-functional and exhibit dominant effects on wild-type connexin43. J Biol Chem. 2005;280:11458-66.

82. Civitelli R. Connexin43 modulation of osteoblast/osteocyte apoptosis: a potential therapeutic target? J Bone Miner Res. 2008;23:1709-11.

83. Civitelli R, Beyer EC, Warlow PM, Robertson AJ, Geist ST, Steinberg TH. Connexin43 mediates direct intercellular communication in human osteoblastic cell networks. J Clin Invest. 1993;91:1888-96.

84. Dobrowolski R, Sasse P, Schrickel JW, Watkins M, Kim JS, Rackauskas M, Troatz C, Ghanem A, Tiemann K, Degen J, Bukauskas FF, Civitelli R, Lewalter T, Fleischmann BK, Willecke K. The conditional connexin43G138R mouse mutant represents a new model of hereditary oculodentodigital dysplasia in humans. Hum Mol Genet. 2008;17:539-54.

85. Koval M, Harley JE, Hick E, Steinberg TH. Connexin46 is retained as monomers in a trans-Golgi compartment of osteoblastic cells. J Cell Biol. 1997;137:847-57.

86. Civitelli R. Cell-cell communication in the osteoblast/osteocyte lineage. Arch Biochem Biophys. 2008:473:188-92.

87. Stains JP, Watkins MP, Grimston SK, Hebert C, Civitelli R. Molecular mechanisms of osteoblast/osteocyte regulation by connexin43. Calcif Tissue Int. 2014;94:55-67.

88. Ton QV, lovine MK. Determining how defects in connexin43 cause skeletal disease. Genesis. 2013;51:75-82.

89. Plotkin LI, Bellido T. Beyond gap junctions: Connexin43 and bone cell signaling. Bone. 2013;52:157-66.

90. Loiselle AE, Jiang JX, Donahue HJ. Gap junction and hemichannel functions in osteocytes. Bone. 2013;54:205-12.

91. Castro CH, Stains JP, Sheikh S, Szejnfeld VL, Willecke K, Theis M, Civitelli R. Development of mice with osteoblast-specific connexin43 gene deletion. Cell Commun Adhes. 2003;10:445-50.

92. Grimston SK, Brodt MD, Silva MJ, Civitelli R. Attenuated response to in vivo mechanical loading in mice with conditional osteoblast ablation of the Connexin43 gene (Gja1). J Bone Miner Res. 2008;23:879-86.

93. Grimston SK, Goldberg DB, Watkins M, Brodt MD, Silva MJ, Civitelli R. Connexin43 deficiency reduces the sensitivity of cortical bone to the effects of muscle paralysis. J Bone Miner Res. 2011;26:2151-60.

94. Gago-Fuentes R, Carpintero-Fernandez P, Goldring MB, Brink PR, Mayan MD, Blanco FJ. Biochemical evidence for gap junctions and Cx43 expression in immortalized human chondrocyte cell line: a potential model in the study of cell communication in human chondrocytes. Osteoarthritis Cartilage. 2014;22:586-90. 
95. Mayan MD, Gago-Fuentes R, Carpintero-Fernandez P, Fernandez-Puente P, Filgueira-Fernandez P, Goyanes N, Valiunas V, Brink PR, Goldberg GS, Blanco FJ, . Articular chondrocyte network mediated by gap junctions: role in metabolic cartilage homeostasis. Ann Rheum Dis. 2015;74:275-84.

96. Pelaez D, Huang CY, Cheung HS. Isolation of pluripotent neural crest-derived stem cells from adult human tissues by connexin-43 enrichment. Stem Cells Dev. 2013;22:2906-14.

97. Zhang W, Green C, Stott NS. Bone morphogenetic protein-2 modulation of chondrogenic differentiation in vitro involves gap junction-mediated intercellular communication. J Cell Physiol. 2002;193:233-43.

98. Zhang J, Zhang HY, Zhang M, Qiu ZY, Wu YP, Callaway DA, Jiang JX, Lu L, Jing L, Yang T, Wang MQ. Connexin43 hemichannels mediate small molecule exchange between chondrocytes and matrix in biomechanicallystimulated temporomandibular joint cartilage. Osteoarthritis Cartilage. 2014;22:822-30.

99. Mayan MD, Carpintero-Fernandez P, Gago-Fuentes R, Martinez-de-llarduya O, Wang HZ, Valiunas V, Brink P, Blanco FJ. Human Articular Chondrocytes Express Multiple Gap Junction Proteins: Differential Expression of Connexins in Normal and Osteoarthritic Cartilage. Am J Pathol. 2013;182:1337-46.

100. Lloyd SA, Loiselle AE, Zhang Y, Donahue HJ. Connexin 43 deficiency desensitizes bone to the effects of mechanical unloading through modulation of both arms of bone remodeling. Bone. 2013;57:76-83.

101. Genetos DC, Zhou Z, Li Z, Donahue HJ. Age-related changes in gap junctional intercellular communication in osteoblastic cells. J Orthop Res. 2012;30:1979-84.

102. Flenniken AM, Osborne LR, Anderson N, Ciliberti N, Fleming C, Gittens JE, Gong XQ, Kelsey LB, Lounsbury C, Moreno L, Nieman BJ, Peterson K, Qu D, Roscoe W, Shao Q, Tong D, Veitch Gl, Voronina I, Vukobradovic I, Wood GA, Zhu Y, Zirngibl RA, Aubin JE, Bai D, Bruneau BG, Grynpas M, Henderson JE, Henkelman RM, McKerlie C, Sled JG, Stanford WL, Laird DW, Kidder GM, Adamson SL, Rossant J. A Gja1 missense mutation in a mouse model of oculodentodigital dysplasia. Development. 2005;132:4375-86.

103. Zappitelli T, Chen F, Moreno L, Zirngibl RA, Grynpas M, Henderson JE, Aubin JE. The G60S Connexin 43 Mutation Activates the Osteoblast Lineage and Results in a Resorption-Stimulating Bone Matrix and Abrogation of old Age-related Bone Loss. J Bone Miner Res. 2013;28:2400-13.

104. Jiang JX, Siller-Jackson AJ, Burra S. Roles of gap junctions and hemichannels in bone cell functions and in signal transmission of mechanical stress. Front Biosci. 2007;12:1450-62.

105. Watkins MP, Norris JY, Grimston SK, Zhang X, Phipps RJ, Ebetino FH, Civitelli R. Bisphosphonates improve trabecular bone mass and normalize cortical thickness in ovariectomized, osteoblast connexin43 deficient mice. Bone. 2012;51:787-94.

106. Grimston SK, Watkins MP, Brodt MD, Silva MJ, Civitelli R. Enhanced periosteal and endocortical responses to axial tibial compression loading in conditional connexin43 deficient mice. PLoS One. 2012;7:e44222.

107. Lloyd SA, Lewis GS, Zhang Y, Paul EM, Donahue HJ. Connexin 43 deficiency attenuates loss of trabecular bone and prevents suppression of cortical bone formation during unloading. J Bone Miner Res. 2012;27:2359-72.

108. Panchin Y, Kelmanson I, Matz M, Lukyanov K, Usman N, Lukyanov S. A ubiquitous family of putative gap junction molecules. Curr Biol. 2000;10:R473-4.

109. Penuela S, Bhalla R, Gong XQ, Cowan KN, Celetti SJ, Cowan BJ, Bai D, Shao Q, Laird DW. Pannexin 1 and pannexin 3 are glycoproteins that exhibit many distinct characteristics from the connexin family of gap junction proteins. J Cell Sci. 2007;120:3772-83.

110. Chekeni FB, Elliott MR, Sandilos JK, Walk SF, Kinchen JM, Lazarowski ER, Armstrong AJ, Penuela S, Laird DW, Salvesen GS, Isakson BE, Bayliss DA, Ravichandran KS. Pannexin 1 channels mediate 'find-me' signal release and membrane permeability during apoptosis. Nature. 2010;467:863-7.

111. Boassa D, Ambrosi C, Qiu F, Dahl G, Gaietta G, Sosinsky G. Pannexin 1 channels contain a glycosylation site that targets the hexamer to the plasma membrane. J Biol Chem. 2007;282:31733-43.

112. Penuela S, Gehi R, Laird DW. The biochemistry and function of pannexin channels. Biochim Biophys Acta. 2013;1828:15-22.

113. Bao L, Locovei S, Dahl G. Pannexin membrane channels are mechanosensitive conduits for ATP. FEBS Lett. 2004;572:65-8.

114. Ishikawa M, Iwamoto T, Nakamura T, Doyle A, Fukumoto S, Yamada Y. Pannexin 3 functions as an ER $\mathrm{Ca}(2+)$ channel, hemichannel, and gap junction to promote osteoblast differentiation. J Cell Biol. 2011;193:1257-74.

115. Buvinic S, Almarza G, Bustamante M, Casas M, Lopez J, Riquelme M, Saez JC, Huidobro-Toro JP, Jaimovich E. ATP released by electrical stimuli elicits calcium transients and gene expression in skeletal muscle. J Biol Chem. 2009;284:34490-505.
116. Gulbransen BD, Bashashati M, Hirota SA, Gui X, Roberts JA, MacDonald JA, Muruve DA, McKay DM, Beck PL, Mawe GM Thompson RJ, Sharkey KA, Activation of neuronal P2X7 receptor-pannexin-1 mediates death of enteric neurons during colitis. Nat Med. 2012;18:600-4.

117. Locovei S, Wang J, Dahl G. Activation of pannexin 1 channels by ATP through P2Y receptors and by cytoplasmic calcium. FEBS Lett. 2006;580:239-44.

118. Yan Z, Khadra A, Sherman A, Stojilkovic SS. Calcium-dependent block of P2X7 receptor channel function is allosteric. J Gen Physiol. 2011;138:437-52.

119. MacVicar BA, Thompson RJ. Non-junction functions of pannexin-1 channels. Trends Neurosci. 2010;33:93-102.

120. Thompson RJ, Jackson MF, Olah ME, Rungta RL, Hines DJ, Beazely MA MacDonald JF, MacVicar BA. Activation of pannexin-1 hemichannels augments aberrant bursting in the hippocampus. Science. 2008;322:1555-9.

121. Thompson RJ, Zhou N, MacVicar BA. Ischemia opens neuronal gap junction hemichannels. Science. 2006;312:924-7.

122. Penuela S, Gyenis L, Ablack A, Churko JM, Berger AC, Litchfield DW, Lewis JD, Laird DW. Loss of pannexin 1 attenuates melanoma progression by reversion to a melanocytic phenotype. J Biol Chem. 2012;287:29184-93.

123. Seror C, Melki MT, Subra F, Raza SQ, Bras M, Saidi H, Nardacci R, Voisin L, Paoletti A, Law F, Martins I, Amendola A, Bdul-Sater AA,Ciccosanti F, Delelis $O$, Niedergang F, Thierry S, Said-Sadier N, Lamaze C, Metivier D, Estaquier J, Fimia GM, Falasca L, Casetti R, Modjtahedi N, Kanellopoulos J, Mouscadet JF, Ojcius DM, Piacentini M, Gougeon ML, Kroemer G, Perfettini JL. Extracellular ATP acts on P2Y2 purinergic receptors to facilitate HIV-1 infection. J Exp Med. 2011;208:1823-34.

124. Celetti SJ, Cowan KN, Penuela S, Shao Q, Churko J, Laird DW. Implications of pannexin 1 and pannexin 3 for keratinocyte differentiation. J Cell Sci. 2010;123:1363-72.

125. Bond SR, Lau A, Penuela S, Sampaio AV, Underhill TM, Laird DW, Naus CC. Pannexin 3 is a novel target for Runx2, expressed by osteoblasts and mature growth plate chondrocytes. J Bone Miner Res. 2011;26:2911-22.

126. Iwamoto T, Nakamura T, Doyle A, Ishikawa M, De VS, Fukumoto S, Yamada Y. Pannexin 3 regulates intracellular ATP/CAMP levels and promotes chondrocyte differentiation. J Biol Chem. 2010;285:18948-58.

127. Penuela S, Celetti SJ, Bhalla R, Shao Q, Laird DW. Diverse subcellular distribution profiles of pannexin 1 and pannexin 3. Cell Commun Adhes. 2008;15:133-42.

128. Barbe MT, Monyer H, Bruzzone R. Cell-cell communication beyond connexins: the pannexin channels. Physiology (Bethesda). 2006;21:103-14.

129. Xiao Z, Camalier CE, Nagashima K, Chan KC, Lucas DA, de la Cruz MJ, Gignac M, Lockett S, Issaq HJ, Veenstra TD, Conrads TP, Beck GR Jr. Analysis of the extracellular matrix vesicle proteome in mineralizing osteoblasts. J Cell Physiol. 2007;210:325-35.

130. James CG, Appleton CT, Ulici V, Underhill TM, Beier F. Microarray analyses of gene expression during chondrocyte differentiation identifies novel regulators of hypertrophy. Mol Biol Cell. 2005;16:5316-33.

131. James CG, Stanton LA, Agoston H, Ulici V, Underhill TM, Beier F. Genome-wide analyses of gene expression during mouse endochondral ossification. PLoS One. 2010;5:e8693.

132. L. A. Cea, M. A. Riquelme, B. A. Cisterna, C. Puebla, J. L. Vega, M. Rovegno, J. C. Saez. Connexin- and Pannexin-Based Channels in Normal Skeletal Muscles and Their Possible Role in Muscle Atrophy. J. Membr. 2012. Biol. DOI: 10.1007/s00232-012-9485-8.

133. Bargiotas P, Krenz A, Hormuzdi SG, Ridder DA, Herb A, Barakat W, Penuela $\mathrm{S}$, Von EJ, Monyer H, Schwaninger M. Pannexins in ischemia-induced neurodegeneration. Proc Natl Acad Sci U S A. 2011;108:20772-7.

134. P. M. Moon, S. Penuela, K. Barr, S. Khan, C. L. Pin, I. Welch, M. Attur, S. B. Abramson, D. W. Laird, F. Beier. Global and cartilage-specific deletion of Panx3 prevents the development of surgically induced osteoarthritis. J. Molec. Medicine 2015.

135. Badley EM. Arthritis in Canada: what do we know and what should we know? J Rheumatol Suppl. 2005;72:39-41.

136. Goldring MB, Goldring SR. Osteoarthritis. J Cell Physiol. 2007;213:626-34.

137. Roach HI, Aigner T, Soder S, Haag J, Welkerling H. Pathobiology of osteoarthritis: pathomechanisms and potential therapeutic targets. Curr Drug Targets. 2007;8:271-82.

138. Dreier R. Hypertrophic differentiation of chondrocytes in osteoarthritis: the developmental aspect of degenerative joint disorders. Arthritis Res Ther. 2010;12:216

139. Pitsillides AA, Beier F. Cartilage biology in osteoarthritis-lessons from developmental biology. Nat Rev Rheumatol. 2011;7:654-63. 
140. Marino AA, Waddell DD, Kolomytkin OV, Meek WD, Wolf R, Sadasivan KK, Albright JA. Increased intercellular communication through gap junctions may contribute to progression of osteoarthritis. Clin Orthop Relat Res. 2004;422:224-32.

141. Casagrande D, Stains JP, Murthi AM. Identification of shoulder osteoarthritis biomarkers: comparison between shoulders with and without osteoarthritis. J Shoulder Elbow Surg. 2015;24:382-90.

142. Tsuchida S, Arai Y, Kishida T, Takahashi KA, Honjo K, Terauchi R, Inoue H, Oda R, Mazda O, Kubo T. Silencing the expression of connexin 43 decreases inflammation and joint destruction in experimental arthritis. J Orthop Res. 2013;31:525-30.

143. Gago-Fuentes R, Fernandez-Puente P, Megias D, Carpintero-Fernandez P, Mateos J, Acea B, Fonseca E, Blanco FJ, Mayan MD. Proteomic analysis of connexin 43 reveals novel interactors related to osteoarthritis. Mol Cell Proteomics. 2015;14(7):1831-45.

144. Appleton CT, Pitelka V, Henry J, Beier F. Global analyses of gene expression in early experimental osteoarthritis. Arthritis Rheum. 2007;56:1854-68.

145. Lohman AW, Isakson BE. Differentiating connexin hemichannels and pannexin channels in cellular ATP release. FEBS Lett. 2014;588(8):1379-88.

Submit your next manuscript to BioMed Central and we will help you at every step:

- We accept pre-submission inquiries

- Our selector tool helps you to find the most relevant journal

- We provide round the clock customer support

- Convenient online submission

- Thorough peer review

- Inclusion in PubMed and all major indexing services

- Maximum visibility for your research

Submit your manuscript at www.biomedcentral.com/submit
Biomed Central 